UDC 504.4.504:628.316.13

\title{
RESEARCH OF METHODS OF INACTIVATION OF THE ANTIBIOTIC CYPROFLOXACIN IN ORDER TO PREVENT ENVIRONMENTAL POLLUTION AND PROTECT HUMAN HEALTH
}

Article info

Received

19.05.2020

Accepted

24.06.2020

${ }^{1}$ Research Institution

"Ukrainian

Research

Institute of

Environmental

Problems",

6, Bakulina Str.,

Kharkiv, 61166, Ukraine,

${ }^{2}$ National Science Center Kharkiv Institute of

Physics and Technology 1, Akademichna Str., Kharkiv, 61108, Ukraine,

E-mail:

alexandr.vasenko @ gmail.com; rfrfyutk@ gmail.com; soroka.soroka2 @ gmail.com

\section{O. Vasenko ${ }^{1}$, I. Zinchenko ${ }^{1}$, K. Tsytlishvili ${ }^{1}$, V. Bikasov ${ }^{2}$}

Vasenko, O., Zinchenko, I., Tsytlishvili, K., Bikasov, V. (2020). Research of methods of inactivation of the antibiotic cyprofloxacin in order to prevent environmental pollution and protect human health. Scientific Horizons, 07 (92), 19-25. doi: 10.33249/2663-2144-2020-92-7-19-25.

Today the environmental problem of modern society is the rapid contamination of water resources around the world for pharmaceutical products, including antibiotics. According to the University of York $(U K)$, contamination with antibiotics had covered two-thirds of the waterways of the planet. It was established experimentally that $90 \%$ of antibiotics are applied into the surrounding environment: soil and water. Residues of medical drugs fall into rivers via human waste and animals and through the treatment plant, including pharmaceutical companies. On the other hand, under the influence of antibiotics can significantly change the biocenosis of water bodies. And bacteria gradually become immune to the effects of antibiotics. Therefore, the Ukrainian research Institute of ecological problems in cooperation with the National scientific center Kharkiv Institute of physics and technology experimental studies aimed at inactivation of bactericidal properties of antibiotic solution during processing ozone-air mixture. The study assessed the effectiveness of inactivation of antibiotic ciprofloxacin hydrochloride by methods related to deep oxidation AOPS technologies (Advanced Oxidation Processes) on the basis of combinations of ozonation, UV irradiation, treatment with hydrogen peroxide. Shown the prospects of using ozonation and $\mathrm{O}_{3} / \mathrm{UV}$ and $\mathrm{O}_{3} / \mathrm{UV} / \mathrm{H}_{2} \mathrm{O}_{2}$ to reduce the toxic effect of the antibiotic residues of ciprofloxacin relative to the test object $E$. coli in the aquatic environment. Found that ozonation of activated sludge treated with ciprofloxacin, reduces the toxic effect of the antibiotic and promotes the enzymatic activity of the biocenosis of activated sludge.

Key words: antibiotic, test-object, activated sludge, ozonation, UV irradiation, hydrogen peroxide, inactivation of the antibiotic

\section{ДОСЛІДЖЕННЯ СПОСОБІВ ІНАКТИВАЦІЇ АНТИБІОТИКА ЦИПРОФЛОКСАЦИНА 3 МЕТОЮ ПОПЕРЕДЖЕННЯ ЗАБРУДНЕННЯ ДОВКІЛЛЯ ТА ЗАХИСТУ ЗДОРОВ'Я ЛЮДИНИ}

О. Г. Васенко ${ }^{1}$, І. В. Зінченко ${ }^{1}$, К. О. Цитлішвілі ${ }^{1}$, В. М. Бикасов ${ }^{2}$

${ }^{1}$ Український науково-дослідний інститут екологічних проблем, вул. Бакуліна, 6, м. Харків, 61166, Україна

${ }^{2}$ Національний науковий центр Харківський фізико-технічний інститут вул. Академічна, 1, м. Харків, 61108, Україна

Наразі екологічною проблемою сучасного суспільства є стрімке забруднення водних ресурсів всього світу фармацевтичною продукиією, у тому числі, антибіотиками. За даними Йоркського 
університету (Велика Британія), забруднення антибіотиками охопило дві третини водних шляхів планети. Експериментально встановлено, що до $90 \%$ антибіотиків, що застосовуються, потрапляють у довкілля: трунти і водні об'єкти. Залишки медичних препаратів потрапляють в річки через відходи життєдіяльності людини і тварин, а також через очисні споруди, в тому числі, фармачевтичних підприємств. 3 іншого боку, під впливом антибіотиків може суттєво змінюватися біоценоз водних об'єктів. А хвороботворні бактерії поступово стають несприйнятливими до впливу антибіотиків. Тому Украӥнським науково-дослідним інститутом екологічних проблем сумісно 3 Національним науковим центром Харківським фізико-технічним інститутом проведені експериментальні дослідження, спрямовані на інактивацію бактерищидних властивостей розчину антибіотика під час його оброблення озоно-повітряною сумішшю. В ході дослідження проведена оцінка ефективності інактивації антибіотика цииррофлоксачину гідрохлориду методами, щчо відносяться до глибокого окиснення AOPs-технологій (Advanced Oxidation Processes) на основі комбінування озонування, УФ-опромінювання, оброблення пероксидом водню. Показана перспективність використання озонування, а також систем $\mathrm{O}_{3} / У \Phi ~ і ~ \mathrm{O}_{3} / У \Phi / \mathrm{H}_{2} \mathrm{O}_{2}$ для зниження токсичної дї̈ залишків антибіотика циипрофлоксацина щодо тест-об'єкта Escherichia coli у водному середовищі. Встановлено, що озонування активного мулу, обробленого цииррофлоксацином, знижує токсичну дію антибіотика і сприяе підвищенню ферментативної активності біоценозу активного мулу.

Ключові слова: антибіотик, тест-об’єкт, активний мул, озонування, УФ-опромінювання, пероксид водню, інактивачія антибіотика.

\section{Вступ}

Наразі великою проблемою сучасного суспільства у сфері екології $\epsilon$ стрімке забруднення водних ресурсів всього світу фармацевтичною продукцією, у тому числі, антибіотиками, концентрація яких в деяких річках світу перевищує межі безпеки в 300 разів. Як показало глобальне наукове дослідження, ініційоване науковцями Йоркського університету (Велика Британія), забруднення антибіотиками охопило дві третини водних шляхів планети. Так, під час дослідження водних артерій 72-х країн, встановлена присутність в місцевих річках 14 видів найбільш поширених антибіотиків.

Наприклад, у Темзі, було знайдено п'ять найменувань антибіотиків. Наявність у воді одного 3 них - ципрофлоксацина - в три рази перевищило безпечний рівень. А в пробах води 3 річки Дунай науковці з Австрії визначили вміст 7 антибіотиків. Цей факт звертає увагу, тому що до основних притоків Дунаю також входять річки на території нашої країни - Тиса, Серет, Прут. На українській ділянці Дунаю розташовані міста Рені, Ізмаїл, Кілія, Вилкове, а також села Ренійського, Ізмаїльського та Кілійського районів Одеської області.

Під впливом антибіотиків може суттєво змінюватися біоценоз водних об'єктів. А хвороботворні бактерії поступово набувають резистентність до антибіотиків (Escher, 2005).

До останнього часу більшість робіт 3 моніторингу довкілля щодо забруднення антибіотиками проводилася в Європі, Північній Америці та Китаї. Але дуже мало відомо про масштаби проблеми в усьому світі.

Авторами (Akimenko, 2014) експериментально встановлено, що до $90 \%$ антибіотиків, що застосовуються, потрапляють у довкілля: грунт і водні об'єкти. Залишки медичних препаратів потрапляють в річки через відходи життєдіяльності людини і тварин, а також через недосконалу роботу очисних споруд, в тому числі, фармацевтичних підприємств (Akimenko, 2014; Andryuschenko, 2017; Dolina, 2018). За даними Асоціації «Health Care Without Harm» в середньому очисні споруди видаляють тільки близько 80 відсотків фармацевтичних речовин та їх залишків (Heberer, 2005). Навіть використання найсучасніших методів очищення не дозволяє повністю запобігти забрудненню: у очищеній стічній воді залишається до 10 відсотків препаратів. Установлено, що активний мул очисних споруд може акумулювати токсичні речовини, у тому числі, антибіотики (Chen, 2008). Тому важливим завданням $€$ усунення впливу залишків стійких фармацевтичних препаратів антибіотиків на довкілля шляхом ї знешкодження (інактиваціï) (Balcioglu, 2003; Huber, 2003; Gurinovich, 2012).

\section{Матеріали та методи досліджень}

Мета дослідження - оцінка ефективності інактивації антибіотика ципрофлоксацина 
O. Vasenko, I. Zinchenko, K. Tsytlishvili, V. Bikasov

фізико-хімічними методами на основі AOPsтехнологій.

Досліджували зразок антибіотика, що належить до групи фторхинолонів ципрофлоксацина гідрохлорид (надалі - ЦФ). Концентрація розчину ЦФ, що досліджували, склала 5 мг/дм ${ }^{3}$ (за активною речовиною).

Методи дослідження - фізико-хімічні та біохімічні.

Спосіб оброблення антибіотика - фізикохімічні методи: застосування озоно-повітряної суміші (озонування) за витратами озоноповітряної суміші - 1 л/хв. і концентрацією озону (15- 20) $\mathrm{rO}_{3} /$ дм $^{3}$ (барботаж крізь диспергатор); застосування ультрафіолетового опромінювання $\left(\mathrm{УФ);} \mathrm{застосування} \mathrm{пероксиду} \mathrm{водню}\left(\mathrm{H}_{2} \mathrm{O}_{2}\right)\right.$ в концентрації $0,3 \%$; а також комбінування цих методів (період оброблення розчину ЦФ складав $10,20,30$ хвилин).

Для оцінювання бактерицидної активності ЦФ використовували тест-об'єкт - культуру кишкової палички - Escherichia coli B (та біоценоз активного мулу очисних споруд.

Оцінювання бактерицидної активності ЦФ на тест-об'єкт і активний мул у разі оброблення фізико-хімічними методами (Kim, 2010) проводили за біохімічним методом шляхом визначення ферментативної активності дегідрогеназного комплексу (ДГА) мікроорганізмів (тест-об’єкта і активного мулу). Для визначення ДГА використовували модифіковану методику визначення ДГА під час технологічного контролю роботи аеротенків (Popechitelev, 2003; Tupin, 2010). ДГА - є показник метаболізму мікроорганізмів, який відчутно реагує на вплив токсичних речовин, у тому числі, антибіотиків. Шляхом порівняння ДГА тест-об'єкта або активного мулу, що знаходилися в оптимальних умовах існування, 3 ДГА тест-об'єкта або активного мулу після контакту 3 розчином ЦФ, оцінювали ступінь бактерицидних властивостей ЦФ при різних режимах його оброблення.

\section{Результати дослідження і обговорення}

Зразки розчину ЦФ, до і після оброблення озоно-повітряною сумішшю, змішували з суспензією Escherichia coli В (тест-об'єктом) у концен-

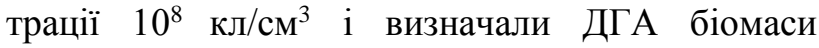
бактерій. Результати впливу зразків ЦФ до і після оброблення на тест-об'єкт надані на рис. 2. Контрольним зразком був тест-об'єкт (суспензія кишкової палички), що не контактував 3 антибіотиком.

Результати впливу зразків ЦФ, оброблених озоно-повітряною сумішшю $\left(20 \mathrm{мг} /\right.$ дм $\left.^{3}\right)$, щодо тест-об' єкта (культури кишкової палички) надані на рис. 1-2.

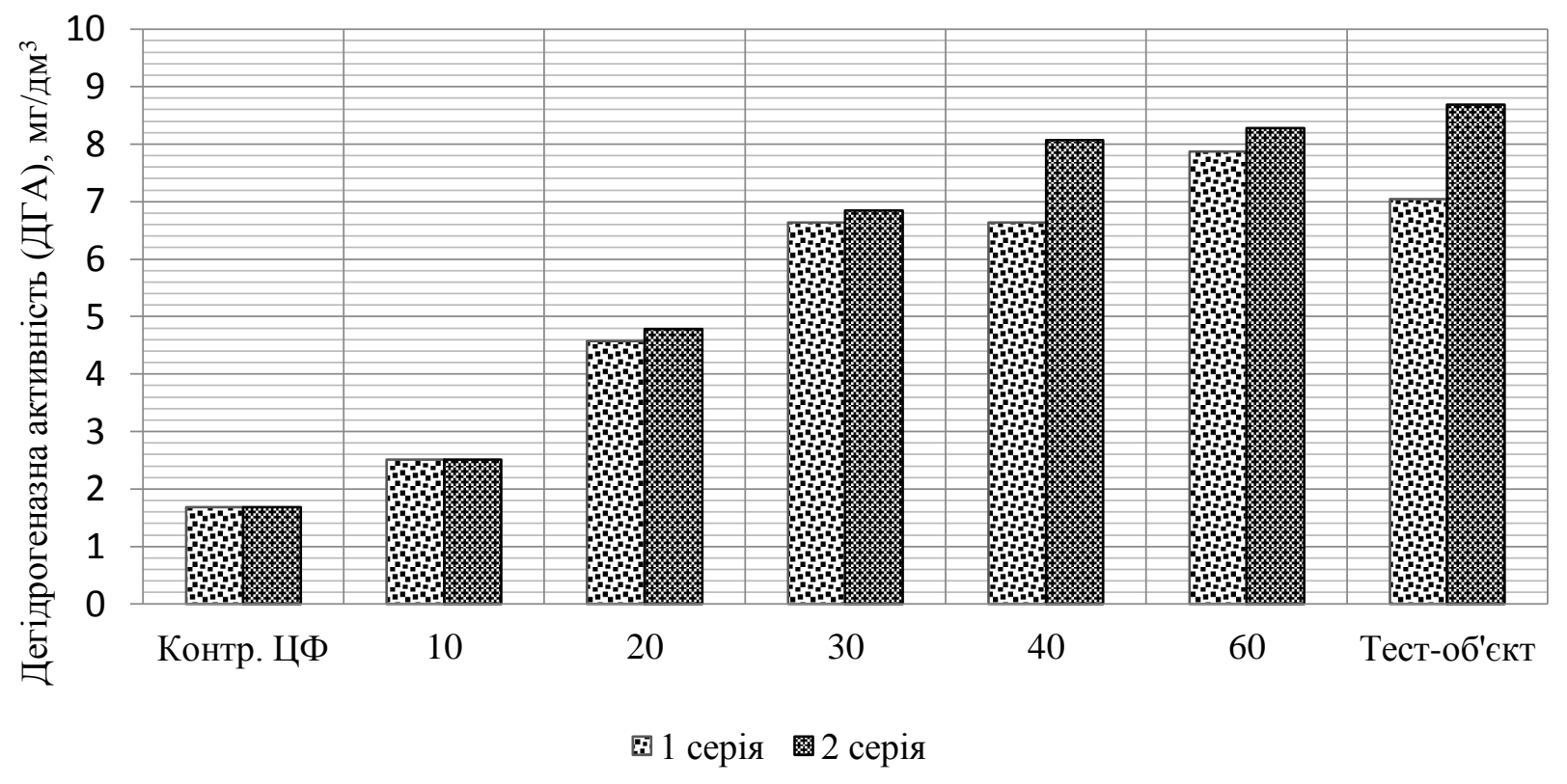

Період оброблення, хв

Рис. 1. Залежність дегідрогеназної активності тест-об'єкта від періоду оброблення розчину ЦФ озоно-повітряною сумішшю 
3 отриманих даних (рис. 1) видно, що ДГА тест-об'єкта в обидних серіях експерименту мала великі значення - 7,04 мг/дм ${ }^{3}$ i 8,69 мг/дм ${ }^{3}$ (токсичний вплив відсутній), проте розчин ЦФ пригнічував життєдіяльність тест-об'єкта, що виражалося у зниженні ферментативної активності мікроорганізмів в 4-5 разів.
Оброблення зразків ЦФ озоном сприяло окисненню антибіотика, розчин якого втрачав бактерицидні властивості і його токсичний вплив на мікроорганізми тест-об'єкта знижувався (рис. 2), що виражалося в збільшенні ДГА мікроорганізмів тест-об'єкта, які контактували 3 обробленими зразками.

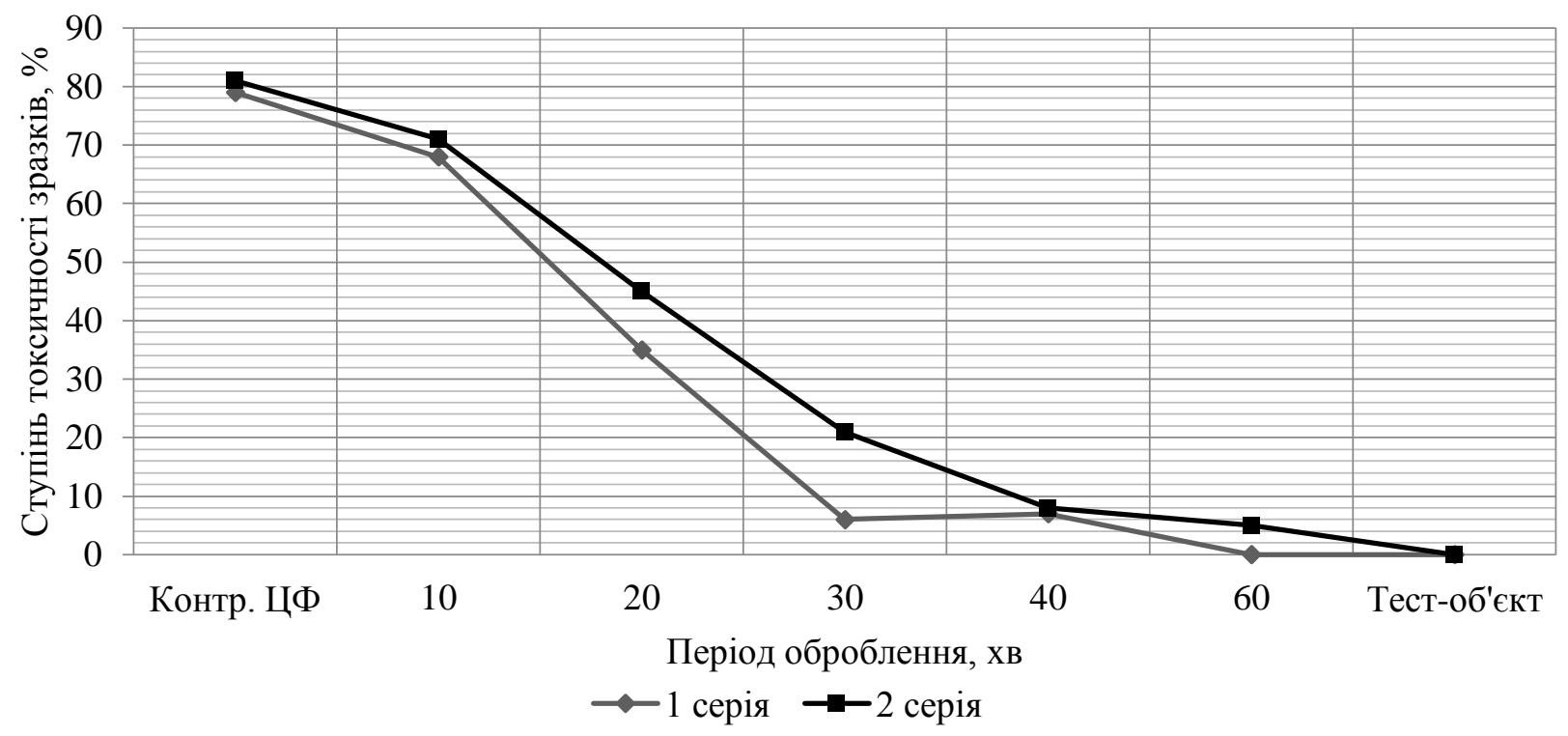

\section{Рис. 2. Залежність ступеня токсичності зразків від періоду їх оброблення озоно-повітряною сумішшю}

Якщо ступінь токсичності розчину ЦФ до оброблення озоно-повітряною сумішшю складала 79-81\%, то оброблення розчину ЦФ дозволило зменшити негативний вплів антибіотика аж до повної його інактивації. Зменшення токсичності залежало від періоду оброблення, так, значний ефект спостерігався після 30 хв. окиснення антибіотика озоном, а за годину оброблення розчин ЦФ практично був інактивований.

В наступній серії досліджень оцінювали бактерицидні властивості антибіотика ЦФ при його обробленні комбінуванням різних методів. Ступінь токсичності (\%) досліджуваних зразків визначали за відношенням різниці між ДГА контролю тест-об'єкта (контрольна проба №1) i ДГА досліджуваної проби до ДГА контролю тестоб'єкта (контрольна проба №2). У табл. 1 і на рис. 3 надані результати дослідження.

ДГА тест-об'єкта (контрольна проба №1) складала 24,24 мг/дм ${ }^{3}$, що відповідає високої активності ферментативної системи бактерій кишкової палички і відсутності токсичності розчину (табл. 1 , п. 1).

ДГА тест-об’єкта при контакті 3 розчином
ЦФ (контрольна проба № 2) має низькі значення $2,08 \mathrm{мг} /$ дм $^{3}$, що свідчить про пригнічення ферментативної системи бактерій кишкової палички. Ступінь токсичності розчину ЦФ відповідає $91 \%$ (табл. 1, п. 2).

У процесі оброблення розчину ЦФ озонуванням і озонуванням сумісно з УФ опромінюванням токсичність розчину ЦФ відносно тестоб'єкта знижується (п. 3-8), що свідчить про інактивацію антибіотика. Водночас найменші значення токсичності спостерігаються при

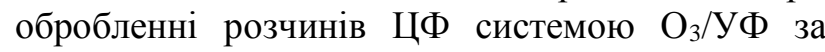
тривалості контакту 20-30 хв. Ступінь токсичності оброблених проб відносно контрольної проби № 2 знижується на (63-72 \%) (табл. 1, п. 7 i $8)$.

Оброблення тест-об'єкта сумісно озоноповітряною сумішшю, УФ-опромінюванням i пероксидом водню $\left(\mathrm{O}_{3} / \mathrm{У} \Phi / \mathrm{H}_{2} \mathrm{O}_{2}\right)$ призвело до повного біоцидного ефекту, за якого ферментативна активність бактерій кишкової палички була пригнічена, що ймовірно пов'язано 3 високим залишковим редокс-потенціалом обробленого, таким способом, розчину ЦФ. 
Таблиия 1. Визначення ДГА тест-об'скта під час контактування з розчином ЦФ до і після його оброблення фізико-хімічними методами

\begin{tabular}{|c|c|c|c|}
\hline $\begin{array}{l}\text { № } \\
\text { 3/II }\end{array}$ & Варіант обробки & $\begin{array}{l}\text { ДГА, мг/дм } \\
\text { (усереднена) }\end{array}$ & $\begin{array}{c}\text { Ступінь } \\
\text { токсичності } \\
\text { зразка, \% } \\
\end{array}$ \\
\hline 1 & $\begin{array}{l}\text { Контрольна проба № } 1 \\
\text { (тест-об’єкт) }\end{array}$ & 24,24 & $\begin{array}{l}\text { Токсичність } \\
\text { відсутня }\end{array}$ \\
\hline 2 & $\begin{array}{l}\text { Контрольна проба № } 2 \text { (антибіотик ЦФ } 5 \text { мг/л + } \\
\text { тест-об’єкт) без обробки }\end{array}$ & 2,08 & 91 \\
\hline 3 & Озонування $\left(\mathrm{O}_{3}\right)(10 \mathrm{xв})$ & 12,68 & 48 \\
\hline 4 & Озонування $\left(\mathrm{O}_{3}\right)(20$ хв) & 14,02 & 42 \\
\hline 5 & Озонування $\left(\mathrm{O}_{3}\right)(30$ хв) & 14,35 & 41 \\
\hline 6 & $\mathrm{O}_{3} / \mathrm{У} \Phi(10 \mathrm{xв})$ & 15,89 & 34 \\
\hline 7 & $\mathrm{O}_{3} / \mathrm{Y} \Phi(20 \mathrm{xB})$ & 17,33 & 28 \\
\hline 8 & $\mathrm{O}_{3} / \mathrm{У} \Phi(30$ хв $)$ & 19,60 & 19 \\
\hline 9 & $\mathrm{O}_{3} / \mathrm{Y} \Phi / \mathrm{H}_{2} \mathrm{O}_{2}(10 \mathrm{xв})$ & відсутня & 100 \\
\hline 10 & $\mathrm{O}_{3} / \mathrm{Y} \Phi / \mathrm{H}_{2} \mathrm{O}_{2}(20 \mathrm{xв})$ & відсутня & 100 \\
\hline 11 & $\mathrm{O}_{3} / \mathrm{Y} \Phi / \mathrm{H}_{2} \mathrm{O}_{2}(30 \mathrm{xв})$ & відсутня & 100 \\
\hline
\end{tabular}

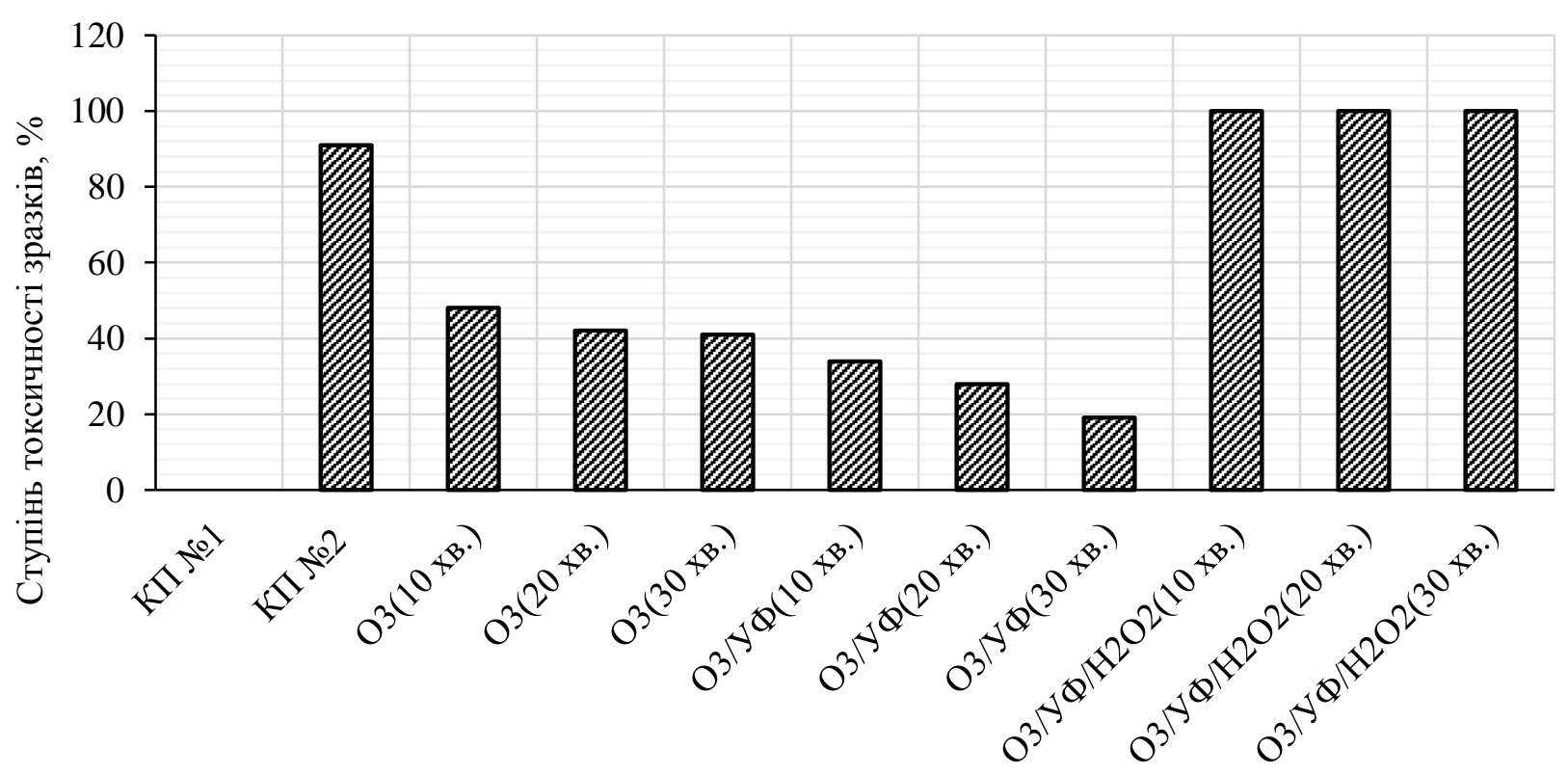

Спосіб і період оброблення

\section{Рис. 3. Залежність ступеня токсичності антибіотика ЦФ від способу і періоду оброблення}

Для визначення впливу розчину антибіотика ЦФ (до і після його оброблення фізико-хімічними методами) на життєздатність мікроорганізмів активного мулу (А.М.), досліджувані зразки змішували з суспензією А.М. (з очисних споруд) 3 наступним визначенням ферментативної активності мікроорганізмів активного мулу. Для визначення безпосереднього впливу на А.M. кожного методу визначали ДГА активного мулу після його оброблення методом, що досліджувався, але без додавання антибіотика ЦФ (контрольні варіанти). Досліджували наступні варіанти обробки активного мулу різними системами фізикохімічних методів:

- A.M. + ЦФ + $\mathrm{O}_{3}$ (обробка протягом 10, 20, 30 $\mathrm{XB}$ );

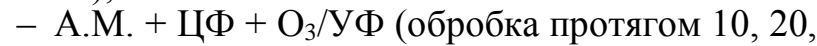
30 хв);

- A.M. + ЦФ $+\mathrm{O}_{3} / \mathrm{H}_{2} \mathrm{O}_{2}$ (обробка протягом 10, 20, 30 хв);

- A.M. + ЦФ $+\mathrm{O}_{3} / У \Phi / \mathrm{H}_{2} \mathrm{O}_{2}$ (обробка протягом $10,20,30$ хв). 
O. Vasenko, I. Zinchenko, K. Tsytlishvili, V. Bikasov

Як контрольні проби були зразки:

- А.М. очисних споруд (К1);

- А.М. очисних споруд + ЦФ (без обробки) (К2);

- А.М. очисних споруд $+\mathrm{O}_{3} /(\mathrm{K} 3)$;
- А.М. очисних споруд $+\mathrm{O}_{3} / У Ф(К 4) ;$

- А.М. очисних споруд $+\mathrm{O}_{3} / \mathrm{У} \Phi / \mathrm{H}_{2} \mathrm{O}_{2}$ (К5).

Результати дослідження наведені в таблиці 2 і рис 3 .

Таблиия 2. ДГА активного мулу при контактуванні з розчином ЦФ (до і після його оброблення фізико-хімічними методами)

\begin{tabular}{|c|c|c|c|}
\hline $\begin{array}{l}\text { № } \\
\text { 3/II }\end{array}$ & Варіант обробки & $\begin{array}{l}\text { ДГА, мг/дм } \\
\text { (усереднена) }\end{array}$ & $\begin{array}{c}\text { Ступінь токсичності } \\
\text { зразка, \% }\end{array}$ \\
\hline 1 & К1 (А.М. очисних споруд) & 105,68 & Токсичність відсутня \\
\hline 2 & К2 (антибіотик ЦФ + А.М.) без обробки & 48,22 & 54 \\
\hline 3 & К3 (А.М.+ $+\mathrm{O}_{3}($ без ЦФ)) & 115,24 & Токсичність відсутня \\
\hline 4 & ЦФ $+\mathrm{O}_{3}(10$ хв $)$ & 82,54 & 22 \\
\hline 5 & ЦФ+ $\mathrm{O}_{3}(20$ хв) & 88,48 & 16 \\
\hline 6 & $Ц \Phi+\mathrm{O}_{3}(30$ хв $)$ & 89,20 & 16 \\
\hline 7 & К4 (А.М.+OㄱㄱУ (без ЦФ)) & 103,24 & 2 \\
\hline 8 & ЦФ + $\mathrm{O}_{3} / У \Phi(10$ м хв $)$ & 90,28 & 15 \\
\hline 9 & ЦФ + $\mathrm{O}_{3} / У \Phi ~(20$ хв $)$ & 91,89 & 13 \\
\hline 10 & ЦФ+ $\mathrm{O}_{3} / У \Phi(30$ хв $)$ & 90,28 & 15 \\
\hline 11 & $Ц \Phi+\mathrm{O}_{3} / \mathrm{H}_{2} \mathrm{O}_{2}(10 \mathrm{xв})$ & 83,73 & 21 \\
\hline 12 & $Ц \Phi+\mathrm{O}_{3} / \mathrm{H}_{2} \mathrm{O}_{2}(20$ хв.) & 90,87 & 14 \\
\hline 13 & $Ц \Phi+\mathrm{O}_{3} / \mathrm{H}_{2} \mathrm{O}_{2}(30$ хв $)$ & 50,96 & 52 \\
\hline 14 & К5 (A.M. $+\mathrm{O}_{3} / \mathrm{У} \Phi / \mathrm{H}_{2} \mathrm{O}_{2}($ без ЦФ)) & 64,88 & 39 \\
\hline 15 & $Ц \Phi+\mathrm{O}_{3} / У \Phi / \mathrm{H}_{2} \mathrm{O}_{2}(10$ хв $)$ & 51,59 & 51 \\
\hline 16 & $Ц \Phi+\mathrm{O}_{3} / \mathrm{У} \Phi / \mathrm{H}_{2} \mathrm{O}_{2}(20$ хв $)$ & 51,59 & 51 \\
\hline 17 & $Ц \Phi+\mathrm{O}_{3} / \mathrm{У} \Phi / \mathrm{H}_{2} \mathrm{O}_{2}(30$ хв $)$ & 48,22 & 54 \\
\hline
\end{tabular}

Мікроорганізми активного мулу виявилися більш стійкі до дії антибіотика ЦФ (5 мг/дм³) (табл. 2, п. 2), ніж культура кишкової палички. Це можна пояснити, 3 одного боку, високою щільністю біомаси А.М., що контактував з ЦФ, 3 іншого боку, тим, що антибіотик має бактерицидну дію, яка спрямована проти бактерій, в той час як до складу А.М. входять різні таксономічні групи (наприклад, гриби, актиноміцети, найпростіші), що мають резистентність до антибіотика.

В пробах контрольних варіантів (А.М. без ЦФ), які були оброблені озонуванням i озонуванням сумісно з УФ-опромінюванням (К3 і К7), ДГА мікроорганізмів А.М. відповідала високим значенням, як і в контрольній пробі К1. Тобто оброблення активного мулу озонуванням, або озонуванням 3 УФ-опромінюванням, не справило (або майже не зробило) токсичної дії щодо А.М. (табл. 2, п. 3 і 7). Навпаки, оброблення А.М. озонуванням збільшило величину ДГА (ферментативну активність) активного мулу (табл. 2, п. 3). Проте в контрольній пробі К5 (А.М. без ЦФ), яка оброблялася сумісно озонуванням,
УФ-опромінюванням і пероксидом водню, визначена досить висока ступінь токсичності $39 \%$ (табл. 2, п. 14), що можна пояснити наслідком процесу оброблення - високим залишковим редокс-потенціалом зразків за рахунок утворення гідроксильних радикалів, які утворюються при сумісній обробці озоном i пероксидом водню.

За даними конкретного експерименту найбільш ефективними способами інактивації ЦФ $є$ оброблення антибіотика озонуванням і озонуванням разом з УФ.

\section{Висновки}

1. Оброблення розчинів антибіотика групи фторхінолонів - ципрофлоксацина гідрохлориду, досліджуваними фізико-хімічними методами призводить до зменшення його бактерицидної дії і ступеня токсичності щодо тест-об'єкта культури бактерій Escherichia coli B i мікроорганізмів активного мулу очисних споруд.

2. Озонування спільно з УФ-опромінюванням (система $\left.\mathrm{O}_{3} / У \Phi\right)$ дозволяє істотно підвищити ефективність окислення ЦФ. Таке поєднання 
O. Vasenko, I. Zinchenko, K. Tsytlishvili, V. Bikasov

можна рекомендувати для інактивації антибіотиків при очищенні стічної води.

3. Попереднє озонування стічних вод може знижувати токсичну дію антибіотиків групи фторхінолонів, а також сприяти підвищенню ферментативної активності активного мулу, що може істотно підвищити ефективність роботи споруд біологічного очищення.

4. Всі досліджені способи оброблення ЦФ, що відносяться до методів глибокого окиснення AOPs-технологіï (Advanced Oxidation Processes), інактивують бактерицидну дію антибіотика. Вибір технологіi знешкодження залишків антибіотиків у воді залежить від складу стічних вод і необхідного ступеня очистки.

\section{References}

Akimenko, Yu. V.,

Kazeev, K. Sh. \& Kolesnikov, S. I. (2014). Vliyanie antibiotikov (benzilpenitsillina, farmazina, nistatina) na biologicheskie svoystva chernozema obyiknovennogo [The effect of antibiotics (benzylpenicillin, pharmazine, nystatin) on the biological properties of chernozem]. Pochvovedenie, 9, 1095-1101 [in Russian].

Andryuschenko, E. (2017, July 17). Lekarstva travyat pitevuyu vodu [Medicines poison drinking water]. Dnepr vecherniy. Retrieved from http://dvgazeta.info/vechyorka/zdorovje/lekarstva-travyatpitevuyu-vodu.html [in Ukrainian].

Balcioglu, I. \& Akmehmet, O. M. (2003). Treatment of pharmaceutical wastewater containing antibiotics by $\mathrm{O}_{3}$ and $\mathrm{O}_{3} / \mathrm{H}_{2} \mathrm{O}_{2}$ processes. Chemosphere, 1, 85-95.

Chen, H. C., Wang, P. L. \& Ding, W. H. (2008). Using liquid chromatography-ion trap mass spectrometry to determine pharmaceutical residues in Taiwanese rivers and wastewaters. Chemosphere, 72 (6), 863-869. doi: 10.1016/j.chemosphere.2008.04.005.

Dolina L. F., Savina O. P. (2018) Ochistka vod ot ostatkov lekarstvennykh preparatov [Water purification from drug residues]. Visnyk Dnipropetrovskoho natsionalnoho universytetu zaliznychnoho transportu, 75 (3), 36-51 [in Ukrainian].

Escher, B. I., Bramaz, N., Eggen, R. I. L. \& Richter, M. (2005). In vitro assessment of models of toxic action of pharmaceuticals in Aquatic life. Environmental science \& technology, 39 (9), 30903100. doi: https://doi.org/10.1021/es048590e.

Gurinovich, A. D., Zhitenev, B. N. \& Voronovich, N. V. (2012). Ochistka prirodnykh vod ot farmatsevticheskikh preparatov metodom okisleniya [Purification of natural waters from pharmaceuticals by oxidation]. Vestnik Brestskogo gosudarstvennogo tehnicheskogo universiteta, 2, 21 27.

Heberer, T. \& Feldmann, D.(2005). Contribution of effluents from hospital and private households to the total loads of diclofenac and carbamazepine in municipal sewage effluents-modeling versus measurements. J. Hazardous Mater, 3, 211-218. doi: 10.1016/j.jhazmat.2005.03.007.

Huber, M. M., Canonica, S., Park, G.-Y. \& von Gunten, U. (2003). Oxidation of pharmaceuticals during ozonation and advanced oxidation processes. Environ. Sci. and Technol, 37 (5), 1016-1024. doi: 10.1021/es025896h.

Kim, I. \& Tanaka, H. (2010). Use of OzoneBased Processes for the Removal of Pharmaceuticals Detected in a Wastewater Treatment Plant. Water Environment Research, 82 (4), 294-301. doi: 10.2175/106143009X12487095236630.

Popechitelev, E. P. \& Startseva. O. N. (2003). Analiticheskiye issledovaniya $\mathrm{v}$ meditsine, biologii $\mathrm{i}$ ekologii [Analytical research in medicine, biology and ecology]. Moskva: Vysshaya shkola [in Russian].

Tupin, P. A., Chukhchin, D. G. \& Novozhilov, A. V. (2010). Razrabotka novogo metoda otsenki fermentativnoy okislitelnoy sposobnosti aktivnogo ila [Development of a new method for assessing the enzymatic oxidative capacity of activated sludge]. Lesnoy zhurnal, 3, 119-124 [in Russian]. 